\title{
Constipation in palliative care: Prevalence, definitions, symptom distress and risk-factors
}

\author{
Eva Erichsén
}

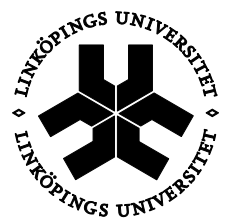

\section{Linköping University}

Department of Social and Welfare Studies

Faculty of Health Sciences

Linköping University, Sweden

Linköping 2015 
CEva Erichsén 2015

Cover/picture/Illustration/Design: Evelina Eklund

Published article has been reprinted with the permission of the copyright holder.

Printed in Sweden by LiU-Tryck, Linköping, Sweden, 2015

ISBN 978-91-7519-101-0

ISSN 1100-6013 
"Lidande upplevs av personer, inte kroppar"

Erik Cassel 


\section{CONTENTS}

\section{ABSTRACT}

\section{LIST OF PAPERS}

\section{INTRODUCTION}

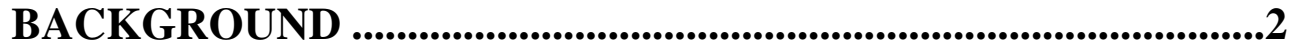

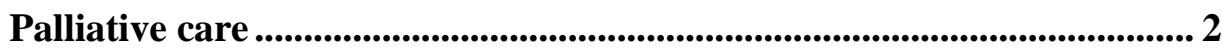

Symptoms in palliative care ................................................................................. 3

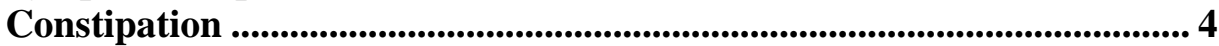

Definition of constipation ............................................................................................... 5

Causes of constipation .................................................................................... 7

Prevalence and assessment of constipation in palliative care.................... 9

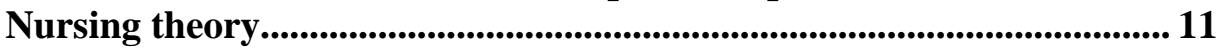

The concept of nursing ......................................................................................... 11

RATIONALE...........................................................................14

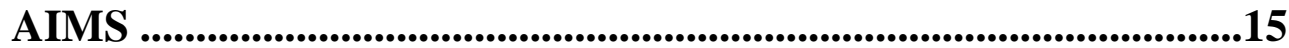

METHODS .................................................................................................16

Design ......................................................................................................................... 16

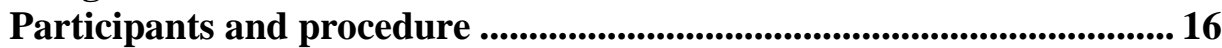

Development of the study questionnaire ........................................................... 18

Statistical analysis ......................................................................................................... 21

Ethical considerations ................................................................................. 22

RESULTS..........................................................................................24

Prevalence, definition and patient-perceived symptom distress (I)....... 25 Factors related to constipation when applying different definitions

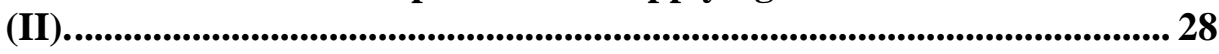

DISCUSSION …...............................................................................30

Methodological issues and limitations ............................................................. 35

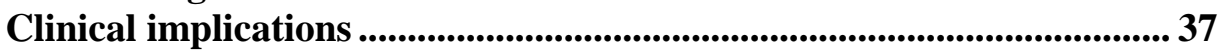

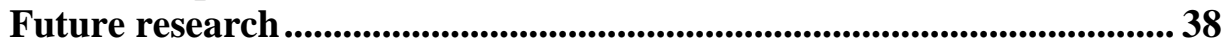

CONCLUSION ........................................................................40

SUMMARY IN SWEDISH ..............................................................41

ACKNOWLEDGEMENTS ....................................................47 
REFERENCE LIST ...............................................................48 


\title{
ABSTRACT \\ Constipation in palliative care; Prevalence, definition, symptom dis- tress and risk- factors
}

\author{
Eva Erichsén \\ Department of Social and Welfare Studies \\ Faculty of Health Sciences \\ Linköping University, Sweden
}

\begin{abstract}
Background and aims: Constipation for patients in palliative care is common and described with variations in prevalence. Side -effects from opioid- treatment, is considered to be one of the main factors leading to constipation. The overall aim of the thesis was to study constipation among patients admitted to specialized palliative care- settings in Sweden. The specific aims of the thesis were 1) To describe and explore the prevalence, definition and symptom distress of constipation by applying different definitions of constipation, in patients admitted to specialized palliative care settings in Sweden. 2) To identify factors related to constipation in patients in specialized palliative care and comparing these factors for patients with different types of constipation to patients without constipation.
\end{abstract}

Methods: A literature- search were conducted where prevalence of- and factors related to constipation was explored and included in a questionnaire, developed for this thesis. Data was collected in a cross- sectional design with a response rate of $50 \%$ and analysed with logistic regression.

Results: A total of 485 patients from 38 specialized palliative care- units in Sweden participated. Prevalence of constipation for patients in specialized palliative care varied between 7- $43 \%$ depending on definition used. Two different constipation- groups were identified: Medical constipation- group 23\% (MCG) and Perceived constipation- group $35 \%$ (PCG). Three sub- groups was also identified: patients with i) only $\leq 3$ defecations/ week, $7 \%$, ii) only perception of being constipated, $19 \%$, and iii) patients with both $\leq 3$ defecations/ week and perception of being constipated,16\%. Several factors were found to be related to constipation as hospitalisation, absence of laxative- treatment, haemorrhoids, poor appetite, hard stool form and opioids.

Conclusions: Prevalence of constipation may differ depending on definitions used. Distress from constipation and other factors related to constipation, than opioids, needs to be incorporated into the clinical constipation- assessment. Validated constipation assessment tool needs to be developed.

Key words: palliative care, constipation, prevalence, definition, symptom-distress, risk factors 


\section{LIST OF PAPERS}

This licentiate thesis is based on the following papers

I. Constipation in specialized palliative care: prevalence, definition and patient- perceived symptom distress.

Erichsén E, Milberg A, Jaarsma T, Friedrichsen M.

Accepted for publication in the Journal of Palliative Medicine (2015)

II. Constipation in palliative care: Factors related to constipation when applying different definitions.

Erichsén E, Milberg A, Jaarsma T, Friedrichsen M.

Submitted to Supportive Care in Cancer 2014

Reprints were made with kind permission from the publisher 


\section{INTRODUCTION}

During my time, working as a nurse in palliative care, I have seen many patients struggling with different symptoms as a consequence from their disease, and ordinary daily life- issues. On top of this, patients in the last phase of their life, may experience considerable discomfort, helplessness and suffering from constipation- problems (Clemens, Klaschik 2008, Dhingra, Shuk et al. 2013, Friedrichsen, Erichsen et al. 2006, ). Even when disease progresses and autonomy impairs, all humans still need to defecate. A basic principle in nursing care is to help patients with their elementary needs when they cannot help themselves, due to illness (Hendersson, Nite 1978). Today, there is a threat that more advanced assessments and treatments occupy the nurses' time, sometimes leaving the basic

needs to the patients themselves (Friedrichsen, Erichsen et al. 2006). This could, in the worst scenario, lead to patients discontinuing opioid treatment for their pain, for fear of becoming constipated (Dhingra, Shuk et al. 2013). In turn, this could lead to increased discomfort and might compromise patients' quality of life, which is not in line with the goal of palliative care (Hjalte, Berggren et al. 2010). Therefore, it is important to study this area so that constipation will be highlighted (Wee, Adams et al. 2010). 


\section{BACKGROUND}

\section{Palliative care}

The term "palliative care" was introduced around 1975 (Mount, Hanks et al. 2006). Later, The World Health Organization (WHO) defined palliative care, mainly for terminally ill patients (Stjernsward, Colleau et al. 1996). A part of WHO:s definition, from 2002, for palliative care is:

“...an approach that improves the quality of life of patients and their families facing the problem associated with life-threatening illness, through the prevention and relief of suffering by means of early identification and impeccable assessment and treatment of pain and other problems, physical, psychosocial and spiritual" (http://www.who.int/cancer/palliative/definition/en/)

Since 2002, WHO has expanded its definition to incorporate patients in an early phase of illness, with ongoing life- prolonging therapies (World Health Organization 2002), to patients in the late palliative phase (The Swedish National Board of Health and Welfare 2013). The "corner- stones" on which palliative care is built, are described as: symptom- relief, cooperation in multi- professional teams, communication and support to relatives (The Swedish National Board of Health and Welfare, 2001). 
In addition, palliative care should be available in all levels of care: primary, secondary and specialized palliative care (World Health Organization 2014). Specialist palliative care is offered to patients with particularly complex symptoms that require specific knowledge and competence in palliative care (Worldwide Palliative Care Alliance 2014). Patients who might be considered for palliative care are those with diagnoses as cancer, chronic obstructive pulmonary disease, stroke, dementia, neurodegenerative disorders, AIDS (World Health Organization 2014) and chronic heart disease (Jaarsma, Beattie et al. 2009). Although patients in palliative care might have different diagnoses, they are often facing similar problems associated with life-threatening illness (Gomes, Calanzani et al. 2013, Worldwide Palliative Care Alliance 2014). Therefore, palliative care should be based on patients' needs instead of diagnoses (Moens, Higginson et al. 2014). Furthermore, palliative care has been shown to be an effective approach to reduce symptoms (Gomes 2014, Ornstein, Wajnberg et al. 2013,) and improve quality of life, regardless of how it is organised (Aoun, O'Connor et al. 2012).

\section{Symptoms in palliative care}

Patients in palliative care suffer from a number of symptoms, such as constipation, fatigue, pain and nausea (Van Lancher, Velge et al. 2014). When it comes to definitions there are differences between a symptom and a sign: "Symptoms are subjective, apparent only to the affected person. A sign, however, is any abnormality indicative of disease, detectable by another person and sometimes by the patient" (Harver, Mahler 1990, p 8). But having a symptom is not the same as 
"symptom experience". According to Dodd, a "symptom experience" is the perception of the symptom (Dodd, Janson et al. 2001), and according to Zambroski it also includes patient's beliefs and responses to symptoms (Zambroski, Moser et al. 2005). An example of patients' symptom experience is a decreased confidence in bodily function when having problems in defecation (Dhingra, Shuk et al. 2013). Symptom burden is described as the multi- dimensional characteristics of symptoms (Zambroski, Moser et al. 2005) and includes the severity, frequency and distress of symptoms (Portenoy, Thaler et al. 1994). Even "mild" symptoms may be experienced as distressful, by the patients (Kirkova, Walsh et al. 2010). Although measurable, the patient's symptom burden is often forgotten in symptom assessments (Dhingra, Shuk et al. 2013). Proper symptom assessment is vital in symptom management and can avoid unnecessary suffering and improve patients' quality of life (Krumm, Larkin et al. 2014, Ornstein, Wajnberg et al. 2013). Although symptom relief is one of the most frequent interventions, in palliative care (Van Mechelen, Aertgeerts et al. 2013) and one of the corner- stones of palliative care, symptoms are not always adequately treated (Laugsand, Jakobsen et al. 2011).

\section{Constipation}

One of the symptoms that are described by patients in palliative care is constipation. It is a common problem (Rhondali, Nguyen et al. 2013, Van Lancker, Velghe et al. 2014) and has been found to be one of the "top 10" of bothersome 
symptoms for patient's receiving palliative care (Esper 2010, Potter, Hami et al. 2003, Walsh, Donnelly et al. 2000). Many symptoms may occur as a consequence from constipation, as abdominal pain, increased weakness (Downing, Kuziemsky et al. 2007), decreased appetite, nausea (Clark, Smith et al. 2012), haemorrhoids, faecal incontinence (Eoff, Lembo 2008), bloating and vomiting (Bader, Jaroslawski et al. 2011).

\section{Definition of constipation}

Today, there is a lack of consensus regarding the definition of constipation in palliative care, and this also plays a part in the reported variance of prevalence in studies (Goodman, Low et al. 2005, Moens, Higginson et al. 2014, Potter, Hami et al. 2003). Several different criteria, such as frequency of bowel movements (with and without concurrent opioid use), opioid or laxative use, self- reports and health professional's opinions, have been used in studies to define constipation (Clark, Currow 2013). A shared definition is crucial in order to establish a more "true" prevalence of constipation (Clark, Currow 2013). Although there is a lack of shared definitions of constipation in palliative care, one definition is often used in palliative- care studies, namely the ROME Criteria (Longstreth, Grant Thompson et al. 2006). These criteria were developed to diagnose functional constipation, a type of constipation that does not include the secondary and iatrogenic causes for constipation (see section about Causes for constipation), something patients in palliative care may suffer from. According to ROME, at least two of the following criteria should be included and be present in at least $25 \%$ of 
defecations: fewer than three defecations per week; straining; lumpy or hard stools; sensation of incomplete evacuation; anorectal obstruction; need of manual manoeuvres to facilitate defecations, and no loose stools without the use of laxatives. These criteria should also be present for the last three months with an onset at least six months prior to diagnosis (Longstreth, Grant Thompson et al. 2006. The authors of the ROME criteria also suggested that the Bristol Stool Form Scale (Lewis, Heaton 1997) with descriptions and visual pictures of stool form, could be used to identify different constipation types.

An adjusted definition of constipation for patients in palliative care has been proposed:

"Constipation is the passage of small, hard faeces infrequently and with difficulty. Individuals vary in the weight they give to the different components of this definition when assessing their own constipation and may introduce other factors, such as pain and discomfort when defecating, flatulence, bloating or sensation of incomplete evacuation" (Sykes, 2004, Larkin, Sykes et al. 2008).

In addition, Clark and Currow (2013) stressed the importance of including the patient's previous experiences of constipation and their objective/subjective sensations, to develop a more thorough and shared definition for constipation in palliative care (Clark, Currow 2013). Patients also tend to define constipation as changes in their experience in passing stool (Clark, Currow 2011) or purely in 
terms of stool consistency (Herz, Kahan et al. 1996). Another complicating factor comes with the fact that some aspects of passing stool may mask constipation. Paradoxical diarrhoea, frequent defecations with loose stools (Lamers 2000) might make it hard for patients, doctors and nurses to define this as constipation. One problem is that validated and reliable instruments for data collection are seldom used today (Van Lancher, Velghe et al. 2014). Another problem is that constipation is often poorly defined, both by clinicians and patients, and that definitions are not commonly shared (Clark, Currow 2013). Both doctors and nurses are often unaware of this and may use their own definition for assessment instead of the patients (Clark, Lam et al. 2014). Physicians define constipation as a physical symptom with changes in stool frequency and appearance (Clark, Urban et al. 2010). To the author`s knowledge there is no explicit definition of constipation from a nursing perspective in this context. It has also been suggested that constipation should be assessed from the patient's perceived symptoms rather than relying on the presence of risk factors (Clark, Lam et al. 2014).

\section{Causes of constipation}

Constipation may be caused by different related factors. This can be described in three categories (Economou 2010):

1) Primary causes, related to reduced fluid or fibre intake (Tarumi 2013), performance level (Clark, Urban et al. 2010, Kamal, Nipp et al. 2015), time or privacy in the toilet (Mazur, Furgala et al. 2012) and old age (Van Lancker, Velghe et al. 2014), lead to dehydration and decreased intestinal peristaltic. 
The normal intestinal peristalsis increases with food intake, through distension, and from the autonomic nervous systems with the release of, for instance serotonin to enhance motility. Reflexes in the gut wall itself, caused by the enteric nervous system, contract the rectum and relax the anal sphincter (Guyton, Hall 2006).

2) Secondary causes are related to structural, metabolic and neurologic disorders, for example pelvic floor weakness (Ayaz, Hisar 2014), hypercalcaemia (Lamy, Jenzer-Closuit et al. 2001) and disease, such as abdominal tumours (Bookbinder, McHugh 2010). This lead to decreased ability to use floor muscles, decreased absorption of water and internal pressure on the intestines.

3) Iatrogenic causes, related to different pharmacological interventions, in palliative care, usually opioids (Economou 2010, Garner 2013) in which case it is called opioid-induced constipation, OIC (Clark, Smith et al. 2012, Davis 2008). Opioids bind to receptors in the intestinal-system (Bell, Panchal et al. 2009), blocking uptake of, for example, serotonin, reducing secretion (necessary for the mixing process in the colon), and decreasing peristalsis and transportation time (Brock, Schou Olesen et al. 2012). An increased tonus in the anal sphincter and reduced secretion lead to hard stool (Guyton, Hall 2006), straining, haemorrhoids and incomplete evacuation (Bell, Panchal et al. 2009). 


\section{Prevalence and assessment of constipation in palliative care}

Constipation for patients in palliative care has been described in various prevalence, from 17-85 \% (Abramowitz, Béziaud et al.2013, Centeno et al. 2009, Clark, Smith et al. 2012, Goodman, Low et al. 2005, Kirkova, Rybicki et al. 2012, Noguera, Centeno et al. 2009, Nübling 2014, Potter, Hami et al. 2003, Rhondali, Nguyen et al. 2013, Saleem 2013, Van Lancher, Velghe et al. 2014). There are many reasons for why the variation in prevalence of constipation varies, one of them are the previously mentioned different definitions used in studies.

But there are also other explanations for the differences in prevalence, such as different care settings in which constipation was reported and different measurements and assessments used in studies. The differences in care settings could for example be seen when comparing hospice and outpatient care. Patients receiving palliative care in hospice and community services reported a higher prevalence of constipation (52\% vs. $35 \%$ ) than patients receiving help from hospital advisory teams or outpatient services (22\% vs. 17\%) (Potter, Hami et al. 2003). This could indicate that the prevalence becomes higher when palliative care patients are in institutions. However, there are studies that still showed high prevalence (43\%) of constipation among outpatients with ALS and Parkinsonism (60\%) (Nübling 2014, Saleem 2013), probably as a consequence of neurological problems. 
Another reason for the reported difference on prevalence of constipation is depending on different measurements used in different studies. Buzgova et al. (2014) used the Patient Needs Assessment in Palliative Care (PNAP) for patients admitted to hospital, and identified $17 \%$ of patients with constipation (Buzgova, Sikorova et al. 2014). With the use of the Symptom Assessment Scale, $42 \%$ of patients in community palliative care were identified with constipation (Clark, Smith et al. 2012). By using the eastern European cooperative oncology group performance scale (ECOG PS) $52 \%$ of patient's admitted to a palliative medical program, was identified (Kirkova, Rybick 2012). However, symptom assessment tools do not provide a specific assessment of constipation (Clark, Smith et al. 2012). However, with more constipation specific measurement, for example the Constipation Visual Analog Scale (0-7) (CVAS) Goodman identified 39\% of patients with constipation, in palliative care day services (Goodman, Low 2005). For patients in a palliative care unit, Cheng (2013) identified 51\% patients suffering from constipation and $30 \%$ of the patients with severe constipation (Cheng, Kwok et al. 2013). Even though validated instruments are not always used it still seems possible to identify around 50\% of patients with constipation (Van Lancher, Velghe 2014). Patients with advanced cancer, in a supportive care clinic, were assessed with modified ROME- criteria and in this study $50 \%$ of patients were identified with constipation (Rhondali, Nguyen et al. 2013). Finally, there could be other reasons for prevalence- differences, like prioritizing other distressing symptoms instead of constipation in palliative care (Bruera, Suarez 1994, Larkin, Sykes et al. 2008). 


\section{Nursing theory}

The theoretical background for this thesis is Henderson's Concept of Nursing, describing basic human needs (Henderson 1997, Henderson, Nite 1978). Elimination is described as one of the basic human needs, common to all people, and nursing is described as primarily helping patients with daily activities. The nurses' role in palliative care is to give patients the support they need with these activities. She claims that nurses should: "sense patients" needs and wishes, their symptoms and responses to treatment, their fear and anxieties, their hopes and the way they want to die" (Henderson, Nite, 1997, p 1963).

\section{The concept of nursing}

In The Basic Principles of Nursing, Henderson (1997) identified common elements of nursing, independently of medical technology and medicine, with the aim to clarify the nursing role.

"The unique function of the nurse is to assist the individual, sick or well, in the performance of those activities contributing to health or its recovery (or to peaceful death) that the person would perform unaided given the necessary strength, will or knowledge. And to do this in such a way as to help the individual gain independence as rapidly as possible”. (Henderson 1997, p 22)

According to Henderson (1980), nurse's main focus is to support patients when problems arise from aberrations, and then provide care necessary for specific clinical conditions. Henderson (1980) also stresses that technological develop- 
ment may compromise the essence of nursing, or basic nursing care and therefore nurses have to strengthen their profession with nursing research (Henderson 1980). Henderson (1982) describes that nurses need to determine problems and plan solutions, with the patients, not for them. Furthermore, they should implement these plans and evaluate them (Henderson 1982). She also describes 14 fundamental needs, or daily activities, that nurses needs to be able to recognize and assess. Having these needs met would support patients to live as normally as possible, in spite of illness. One of the 14 fundamental needs according to Henderson (1997) is to eliminate body wastes. The other 13 being: breathing, eating and drinking, moving, sleeping and resting, maintaining normal body temperature, keeping the body clean and clothed, avoiding injury, being able to communicate, maintaining faith, learning and working, play and recreation (Henderson 1997). Henderson (1978) stress that nurses should have knowledge about elimination and "normal" ranges of defecation. Problems with elimination may be detected from smell, appearance of faeces and tension in the patient. Nurses should also know that talk on elimination may be "taboo", due to its sensitive nature, which might restrain patients from mentioning this subject (Henderson, Nite 1978).

Although Henderson's Concept of Nursing is an old theory, the basic thoughts are still relevant to nursing practice. In acknowledging the patient as an individual with basic human needs, nurses might through their profession, support pa- 
tients in their distress. Henderson's work is one of the bases for further development of fundamental aspects of nursing (Kitson, Conroy et al. 2010). 


\section{RATIONALE}

Constipation may decrease quality of life for patients in palliative care and that is the main reason for writing this thesis. Previously, the prevalence of constipation has been reported with great variations in the palliative care setting. One can ask why? Previous studies have focused on many different symptoms, which give a brief picture of symptom prevalence but only a few studies (Clark, Smith et al. 2012, Noguera, Centeno et al. 2009, Rhondali, Nguyen et al. 2013) have focused deeper on one particular symptom, and dig deeper. To do this, was the second reason for writing this thesis. In constipation research, in palliative care, most focus has also been on measurable objective factors leading to constipation, for example side-effects from opioid- treatment (Davis 2008), so called opioid- in-

duced constipation. However, this is not the only factor (Clark, Byfieldt et al. 2012) that increases constipation in the palliative care setting. Therefore I was interested to study other factors that are related to constipation that might help to improve nursing care for these patients. 


\begin{abstract}
AIMS
The overall aim of the thesis was to study constipation among patients admitted to specialized palliative care settings in Sweden. The specific aims of the thesis were as follows:
\end{abstract}

\title{
Study I
}

To describe and explore the prevalence, definition and symptom distress of constipation by applying different definitions of constipation, in patients admitted to specialized palliative care settings in Sweden.

Study II

To identify factors related to constipation in patients in specialized palliative care and comparing these factors for patients with different types of constipation to patients without constipation. 


\section{METHODS}

\section{Design}

For both studies in this thesis, a descriptive study with a national cross- sectional survey was conducted.

\section{Participants and procedure}

Both studies in this thesis were based on the same sample. A consecutive selection from Palliativguiden 2010 (a compilation of palliative- care settings in Sweden) was made to identify specialist palliative care units in Sweden (www.nrpv.se). The study unit's participation was decided in two steps. First, palliative care units were included if they i) provided care for a minimum of 10 patients with life- threatening illnesses, ii) provided care at the unit's own ward or in the patient's own home and iii) provided access to health- care personnel every day, 24 hours a day, and fulfilled the criteria for specialized palliative care units (The Swedish National Board of Health and Welfare, 2001, Worldwide Palliative Care Alliance 2014). From a total of 128 palliative care units, 63 were excluded as they did not meet the inclusion- criteria. All remaining 65 registered units were contacted to confirm the inclusion criteria and when appropriate, to request their participation. Due to lack of time/reorganization, 21 units declined to participate. Units accepting participation were sent written information, with reminders sent out some two weeks after the first contact. Signed acceptance to 
participate in the study was collected from each head of the units. Six units discontinued participation during the study-period, leaving 38 units. Second, patients were included if they were: admitted to one of the 38 participating units and over 18 years of age. Patients did not have to be diagnosed with or have symptoms/signs of constipation. Exclusion criteria were non Swedish speaking patients and patients with cognitive failure, assessed by the nurses at the participating unit. The nurses of the palliative care unit also informed the patients, written and oral, on the study.

The included 38 units had 1287 patients admitted, during the time of data collection (2012-10-11 to 2012-11-11). After exclusion $(\mathrm{n}=319)$ and other reasons for not participating $(n=453), 515$ patients were included. Incomplete data $(n=30)$ resulted in a total of 485 complete datasets (Figure 1).

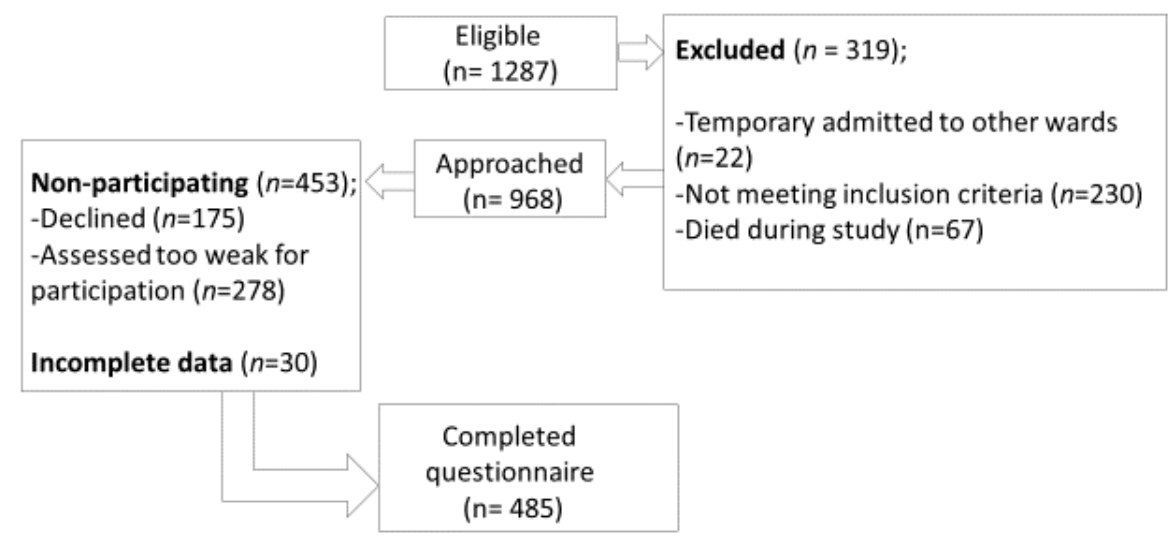

Figure 1. Flowchart of patient selection process. 


\section{Development of the study questionnaire}

To select the appropriate way for collecting data a general literature- search was made (Polit, Beck 2012) on constipation and related factors. Six valid and reliable instruments on constipation were selected and especially scrutinized for factors related to constipation (Downing, Kuziemsky et al. 2007, Kyle, 2007, Larkin, Sykes 2008, Lewis, Heaton 1997, McMillan, Williams 1989, Richmond, Wright 2008) (Table 1).

Table 1. Scales and guidelines scrutinized for factors related to constipation

\begin{tabular}{|l|l|l|l|l|}
\hline Instrument & Target group & Assessment & \multicolumn{1}{|c|}{$\begin{array}{l}\text { Factors related } \\
\text { to constipation }\end{array}$} & Author \\
\hline $\begin{array}{l}\text { Norgine }{ }^{\circledR} \text { Risk } \\
\text { Assessment Tool } \\
\text { for Constipation }\end{array}$ & $\begin{array}{l}\text { Elderly/ } \\
\text { palliative } \\
\text { care }\end{array}$ & $\begin{array}{l}\text { Risk/ } \\
\text { management }\end{array}$ & $\begin{array}{l}\text { Age, Diagnose, } \\
\text { Medication, Mobility, } \\
\text { Nutrition, Appear- } \\
\text { ance, Toilet facilities, } \\
\text { Rectal- problems }\end{array}$ & Kyle 2007 \\
\hline $\begin{array}{l}\text { CAS Constipation } \\
\text { Assessment Scale }\end{array}$ & Cancer care & $\begin{array}{l}\text { Risk/ } \\
\text { assessment }\end{array}$ & $\begin{array}{l}\text { Medication Mobility } \\
\text { Nutrition }\end{array}$ & $\begin{array}{l}\text { McMillan, } \\
\text { Williams 1989 }\end{array}$ \\
\hline $\begin{array}{l}\text { BSFS } \\
\text { Bristol Stool Form } \\
\text { Scale }\end{array}$ & $\begin{array}{l}\text { Functional } \\
\text { constipation }\end{array}$ & $\begin{array}{l}\text { Appearance of } \\
\text { faeces }\end{array}$ & Appearance & $\begin{array}{l}\text { Lewis, } \\
\text { Heaton 1997 }\end{array}$ \\
\hline $\begin{array}{l}\text { VBPS } \\
\text { Victoria Bowel }\end{array}$ & $\begin{array}{l}\text { Hospice/ } \\
\text { Palliative } \\
\text { care }\end{array}$ & $\begin{array}{l}\text { Evaluation of } \\
\text { established } \\
\text { constipation }\end{array}$ & $\begin{array}{l}\text { Medication Mobility } \\
\text { Nutrition Appearance } \\
\text { of faeces, } \\
\text { Patients experience }\end{array}$ & $\begin{array}{l}\text { Downing, } \\
\text { Kuziemsky 2007 } \\
\text { Hawley et al. } \\
\text { 2011 }\end{array}$ \\
\hline $\begin{array}{l}\text { CRAS } \\
\text { Constipation Risk } \\
\text { Assessment Scale }\end{array}$ & Cancer- care & Risk & $\begin{array}{l}\text { Gender Medication } \\
\text { Mobility Nutrition, } \\
\text { Learning-problems, } \\
\text { Patients experience } \\
\text { Toilet facilities } \\
\text { Rectal- problems }\end{array}$ & $\begin{array}{l}\text { Richmond, } \\
\text { Wright 2008 }\end{array}$ \\
\hline $\begin{array}{l}\text { Clinical Recom- } \\
\text { mendations }\end{array}$ & $\begin{array}{l}\text { Palliative } \\
\text { care }\end{array}$ & $\begin{array}{l}\text { Risk/ } \\
\text { managnoment Medication } \\
\text { Mobility Nutrition } \\
\text { Toilet facilities } \\
\text { Rectal- problems }\end{array}$ & $\begin{array}{l}\text { Larkin, Sykes } \\
\text { 2008 }\end{array}$ \\
\hline
\end{tabular}


To measure prevalence, definition, symptom distress and other factors related to constipation, questions from Swedish versions of validated questionnaires were used (Table 2). All the factors identified by other instruments were measured, with exception of the factor of learning problems (Richmond, Wright 2008). The reason for this was that this was judged to be too time consuming for the nurses to assess. For some factors we could not find validated questionnaires and these items were constructed by the researcher (Table 2).

To include all constipation- related data, collected for this thesis, a 26- item questionnaire were developed. The questionnaire contained two sections. One section were completed by the nurses, with four questions addressing place of care, diagnose, pharmacological treatment, from the patients' medical records. The second section was completed by the patient and included 22 questions on demographical data, such as gender, living conditions, age and educational level, mobility, appetite, nutrition, toilet visits, anal problems, frequency, definition, distress, self-care, information and appearance of faeces. Two questions were used to identify the prevalence of constipation: "How often have you moved your bowels during the last two weeks?" (every day to several times/day) and "Have you experienced constipation during the last two weeks (yes/no)?” 


\begin{tabular}{|c|c|c|c|}
\hline CONCEPT & ITEM & RESPONSE & SCALE-SOURCE \\
\hline Mobility & $\begin{array}{l}\text { Walking without problems- } \\
\text { bed restricted }\end{array}$ & $\begin{array}{l}1 \text { (no walking problems) - } 3 \text { (confined to } \\
\text { bed) }\end{array}$ & $\begin{array}{l}\text { HRQoL EQ-5D } \\
\text { Health Related Quality of Life EQ- } \\
\text { 5D (Brooks 1996) }\end{array}$ \\
\hline Appetite & Appetite loss & 1 (not at all)-3 (very much) & $\begin{array}{l}\text { EORTC QLQ-C15 PAL } \\
\text { European Organization for Re- } \\
\text { search and Treatment of Cancer- } \\
\text { Palliative Care questionnaire -C } \\
15 \text { PAL } \\
\text { (Groenvold, Petersen et al. 2006) }\end{array}$ \\
\hline $\begin{array}{l}\text { Nutritional } \\
\text { intake }\end{array}$ & Meals/day & 1 (one meal/day) -4 ( $\geq 3$ meals/day) & $\begin{array}{l}\text { MNA } \\
\text { Minimal Nutrition Assessment } \\
\text { (Guigoz 2006) }\end{array}$ \\
\hline Toilet facilities & $\begin{array}{l}\text { Need of personal support, } \\
\text { bedpans/diapers }\end{array}$ & Yes/No & $\begin{array}{l}\text { Norgine }^{\circledR} \text { Risk Assessment Tool } \\
\text { for Constipation (Kyle 2007) }\end{array}$ \\
\hline Appearance & Appearance of feaces & 1 (hard lumps)- 7 (mushy stool) & $\begin{array}{l}\text { BSFS } \\
\text { Bristol Stool Form Scale } \\
\text { (Lewis, Heaton 1997) } \\
\end{array}$ \\
\hline $\begin{array}{l}\text { Symptom- } \\
\text { distress }\end{array}$ & $\begin{array}{l}\text { How severe } \\
\text { How distressful } \\
\text { How often }\end{array}$ & $\begin{array}{l}1 \text { (slightly) - } 4 \text { (very severe) } \\
1 \text { (not at all) }-4 \text { (very much) } \\
1 \text { (rarely) - } 4 \text { (almost constantly) }\end{array}$ & $\begin{array}{l}\text { MSAS Memorial Symptom As- } \\
\text { sessment Scale } \\
\text { (Portenoy, McCarthy et al. 1994) } \\
\text { Constructed by the researcher }\end{array}$ \\
\hline Place of care & $\begin{array}{l}\text { Palliative home- care } \\
\text { Palliative ward- care }\end{array}$ & Yes/No & Constructed by the researcher \\
\hline $\begin{array}{l}\text { Living condi- } \\
\text { tions }\end{array}$ & $\begin{array}{l}\text { Living alone } \\
\text { Cohabitant }\end{array}$ & Yes/No & Constructed by the researcher \\
\hline Prevalence & $\begin{array}{l}\text { Frequency of bowel move- } \\
\text { ments the last two weeks } \\
\text { Perception of being consti- } \\
\text { pated last two weeks }\end{array}$ & $\begin{array}{l}1 \text { (every day)-5 (several times/day) } \\
\text { Yes/No }\end{array}$ & Constructed by the researcher \\
\hline $\begin{array}{l}\text { Patients defi- } \\
\text { nition }\end{array}$ & $\begin{array}{l}\text { In days } \\
\text { In experience }\end{array}$ & $\begin{array}{l}1 \text { to } 4 \text { (no defecation in } 1-2 \text { days- no defe- } \\
\text { cation in }>6 \text { days) } \\
1 \text { to } 4 \text { (straining but able to defecate- hard } \\
\text { straining, little defecation) }\end{array}$ & Constructed by the researcher \\
\hline $\begin{array}{l}\text { Self- care } \\
\text { Non- medical- } \\
\text { self- care }\end{array}$ & $\begin{array}{l}\text { No self- care, increasing } \\
\text { movement try again later, } \\
\text { stay longer at the toilette or } \\
\text { using prunes, linseed or drink- } \\
\text { ing more water } \\
\text { Taking enemas/ laxatives }\end{array}$ & $\begin{array}{l}\text { Yes/No } \\
\text { Yes/No }\end{array}$ & Constructed by the researcher \\
\hline Information & $\begin{array}{l}\text { Received information on con- } \\
\text { stipation } \\
\text { Satisfied with information } \\
\text { given }\end{array}$ & Yes/No & Constructed by the researcher \\
\hline
\end{tabular}


To validate the questionnaire, a pilot study was undertaken in a specialized palliative care setting. Discussions on readability, understanding, estimated time and work effort, were conducted with experts in palliative care: four patients, three doctors and five nurses in a specialist palliative care setting (Polit, Beck 2012). Small changes in the wording were made from this, without affecting the specific content of the questionnaire. Thereafter, and with 20 patients completing the questionnaire, no more changes were suggested.

\section{Statistical analysis}

To present the characteristics of the studied population, descriptive statistics with mean and standard deviation (SD) were used for continuous variables and frequencies and percentages for categorical data. $\mathrm{T}$ - test and Chi square-test were calculated on age and gender for participating patients and patients declining participation. Patients with $\leq 3$ defecations were labelled as the Medical Constipation Group, MCG. Patients with the perception of being constipated were identified and labelled as the Perceived Constipation Group, PCG. Factors related to constipation were all considered to be independent variables and different constipation groups were the dependent variables. Response alternatives in the questionnaire were dichotomized with a yes/no- answer. Factors with $\geq 5 \%$ prevalence, were analysed with binary logistic regression, for both studies, to calculate odds ratio (OR) with $95 \%$ confidence intervals $(\mathrm{CI})$, in a univariate model. OR were analysed for constipated patients compared to non-constipated, for internal comparison between different constipation-groups, and for comparisons between 
different constipation-groups and non-constipated patients (Bland, Altman 2009). A level of $p<0.05$ was considered statistically significant and all analyses were performed using IBM SPSS Statistics, version 21.

\section{Ethical considerations}

Patients in palliative care are an especially vulnerable group and including these patients in research can be perceived as challenging (Casarett, Karlawish 2000). This challenge may be due more to a "taboo" against speaking about death and dying, than to ethical concerns (Terry, Olson et al. 2006). It may be considered unethical not to include palliative care patients in research and to underestimate their capability to decide to participate in studies and give informed consent (Wohleber, McKitrick et al. 2012). The risks and benefits of studies on patients in palliative care are not easy to assess (Casarett, Karlawish 2000) so research must carefully incorporate patients' preferences and expectations. Patients may feel forced to participate in research, due to gratitude or dependence, which may affect voluntariness (Casarett, Karlawish 2000). Still, many patients willingly participate in order to help other patients (Wohleber, McKitrick et al. 2012) and may also feel that they are able to make a useful contribution, despite their terminal illness (Terry, Olson et al. 2006). A questionnaire survey may also cause discomfort and be burdensome (Wohleber, McKitrick et al. 2012). Therefore, patients in current studies were encouraged to fill out the questionnaire with another person present. 
Guidelines on ethical issues in palliative care research have been suggested. These could facilitate the participation of patients with time- varying symptoms and different levels of cognition, and may also limit the control and restriction of patient's access to participation, such as gatekeeping and paternalistic attitudes, and change the research culture in palliative care (Gysels, Evans et al. 2013). In the current study, 278 patients were assessed to be "too weak" to participate and it is unknown if they were even asked or considered by the nurses.

To preserve the participating unit's confidentiality, all participating units received pre-addressed coded envelopes for returning of completed questionnaires. All participating patients were also given written information on the study and their right to decline, or to discontinue participation at any time. Patients who accepted to participate gave oral informed consent to the nurse involved. To preserve confidentiality, no patient information apart from the patient's age and gender was recorded on the questionnaire. Completed questionnaires were to be kept in a locked place at the unit, before they were sent back to the author. Received questionnaires were marked with the unit's code number, followed by consecutive numbers representing the numbers of completed questionnaires. These were then kept in a locked box to which only the author had access. The study was conducted according to the Declaration of Helsinki and was approved by the Regional Ethical Review Board in Linköping (Dnr: 2012/203-31). 


\section{RESULTS}

Data from 485 participating patients were analysed (Table 3). There were no statistical differences regarding gender $(\mathrm{p}=0.40)$ or age $(\mathrm{p}=0.17)$ between participating patients $(n=485)$ and patients declining to participate $(n=175)$.

Table 3. Characteristics of the study population $(n=485)$

\begin{tabular}{|lr|}
\hline Variables & \\
Age mean (SD) & $\mathbf{N}(12)$ \\
Variables & $261(54)$ \\
Female gender & $286(59)$ \\
Cohabitant & $120(25)$ \\
University education & $390(80)$ \\
Palliative home- care & \\
Cancer* & $419(86)$ \\
Heart disease* & $80(16)$ \\
Pulmonary disease* & $81(17)$ \\
& $300(62)$ \\
Opioid- treatment & $237(49)$ \\
Laxative- treatment & $398(82)$ \\
Use of $>5$ medications/day & \\
\hline
\end{tabular}

* The patients could have more than one diagnosis

Of the participating 38 units, eight had written guidelines on constipation management and no unit used a validated instrument specifically for constipationassessment. One unit used the Edmonton Symptom Assessment Scale, ESAS, a validated instrument for general symptom assessment (Bruera, Kuehn et al. 1991). Seven other units used local guidelines on treatment of constipation. 


\section{Prevalence, definition and patient-perceived symptom distress (I)}

Of the total sample ( $n=485), 207$ patients $(43 \%)$ were identified with constipation. Twenty- three percent $(114 / 485)$ had constipation identified from $<3$ bowel movements a week, MCG, and 35\% of patients (171/485) were identified from the perception of being constipated, PCG (Figure 2). Of the total number of constipated patients, the MCG constituted $55 \%$ (114/207) and the PCG 83\% (171/207). Since some patients had both $<3$ bowel movements a week (MCG) and perception of being constipated (PCG) a further refining resulted in three subgroups: MC\&PC 16\% (78/485), PC ONLY 19\% (93/485) and MC ONLY 7\% (36/485) (Figure 2).

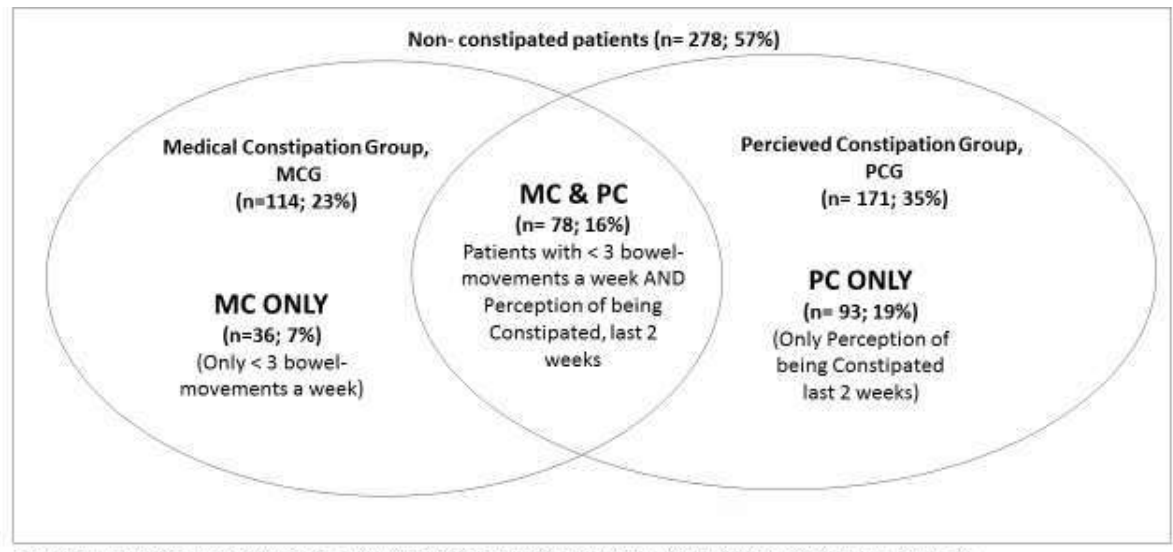

Figure 2. Prevalence of constipation ( $n=485$ ), Constipated patients with MC ONLY, PC ONLY and MC\&PC ( $n=207 ; 43 \%$ ) Medical Constipation Group, MCG = patients with $\leq 3$ defecations/week

Percieved Constipation Group, $P C G=$ patients with a perception of being constipated during the last two weeks Medical Constipation Only, MC ONLY=patients with $\leq 3$ defecations/week

Percieved Constipation Only. PC ONLY=patients with a perception of being constipated during the last two weeks

When looking at how the patients defined their constipation we found that the most common definition of constipation was by frequency between defecations. There were no differences between the three refined- subgroups (Table 4). Pa- 
tients with PC ONLY had higher odds of defining constipation based on experience, compared to MC\&PC. Patients with PC ONLY had lower odds for being often constipated, compared to patients with MC\&PC. Symptom distress was only reported and analysed for PC ONLY and MC\&PC, because these groups experienced themselves as constipated, something patients with MC ONLY did not. PC ONLY had lower odds for distressful constipation compared to MC\&PC. 


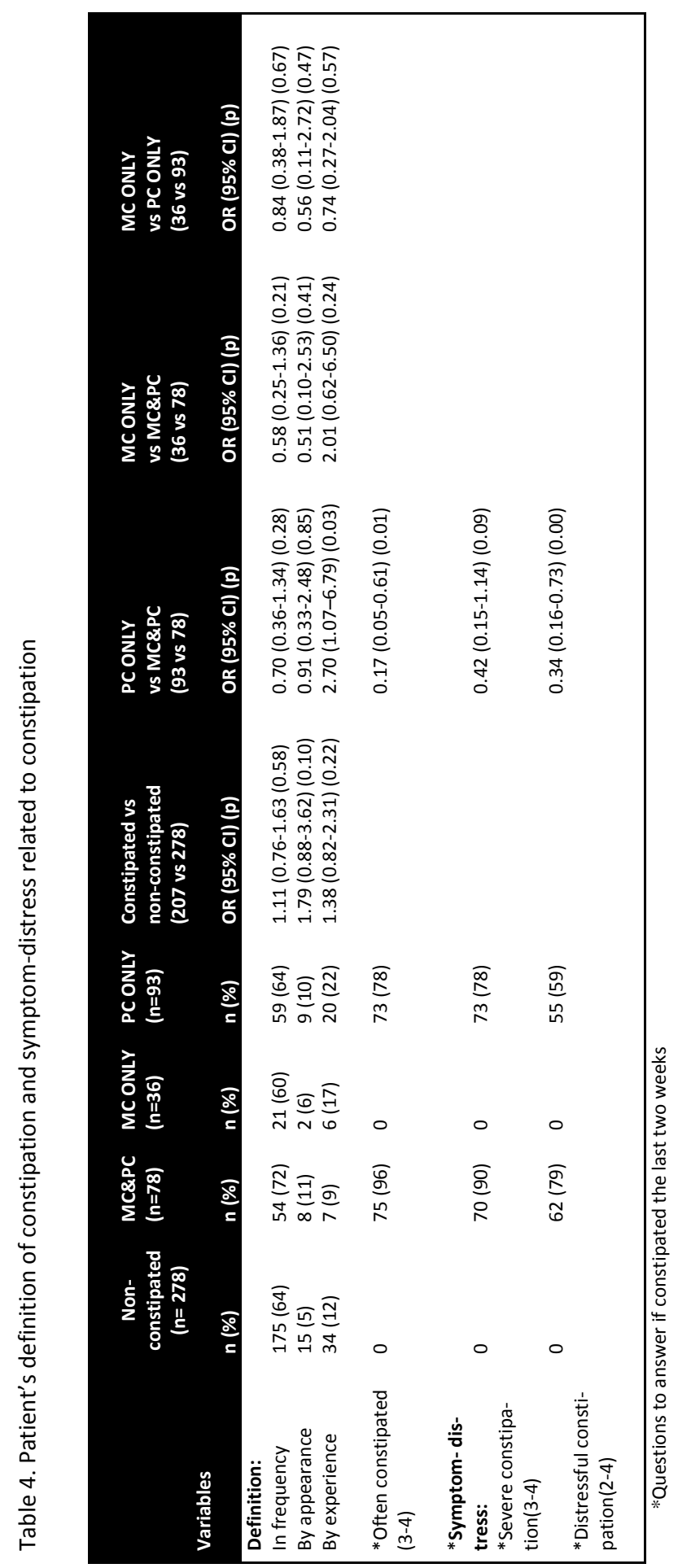




\section{Factors related to constipation when applying different definitions (II)}

In this study, a number of significant factors related to constipation were identified (Table 5). In comparison to non-constipated patients, patients with PC ONLY had significantly higher odds for factors related to constipation, such as (decreasing order): hard- stool form, not satisfied with constipation- information, haemorrhoids, opioids, poor appetite, bed restricted and paracetamol. For patients with PC ONLY compared to non- constipated, the odds were lower for having no university education and no received information on constipation. Patients with MC ONLY had significantly higher odds for (decreasing order): $\leq 1$ cup of flu$\mathrm{id} /$ day, bed restricted, palliative ward-care, toilet- assistance, self- care with laxatives/enemas, compared to non- constipated patients.

Patients with MC\&PC had, compared to non- constipated patients, significantly higher odds for having a hard stool- form, cancer, opioids, self-care with laxatives/enemas, cortisone, poor appetite and paracetamol (decreasing order). $\mathrm{Pa}$ tients with MC\&PC had, significantly lower odds for having no laxatives, no received constipation- information and radiation therapy last month, compared to non- constipated patients (decreasing order) (Table 5). 


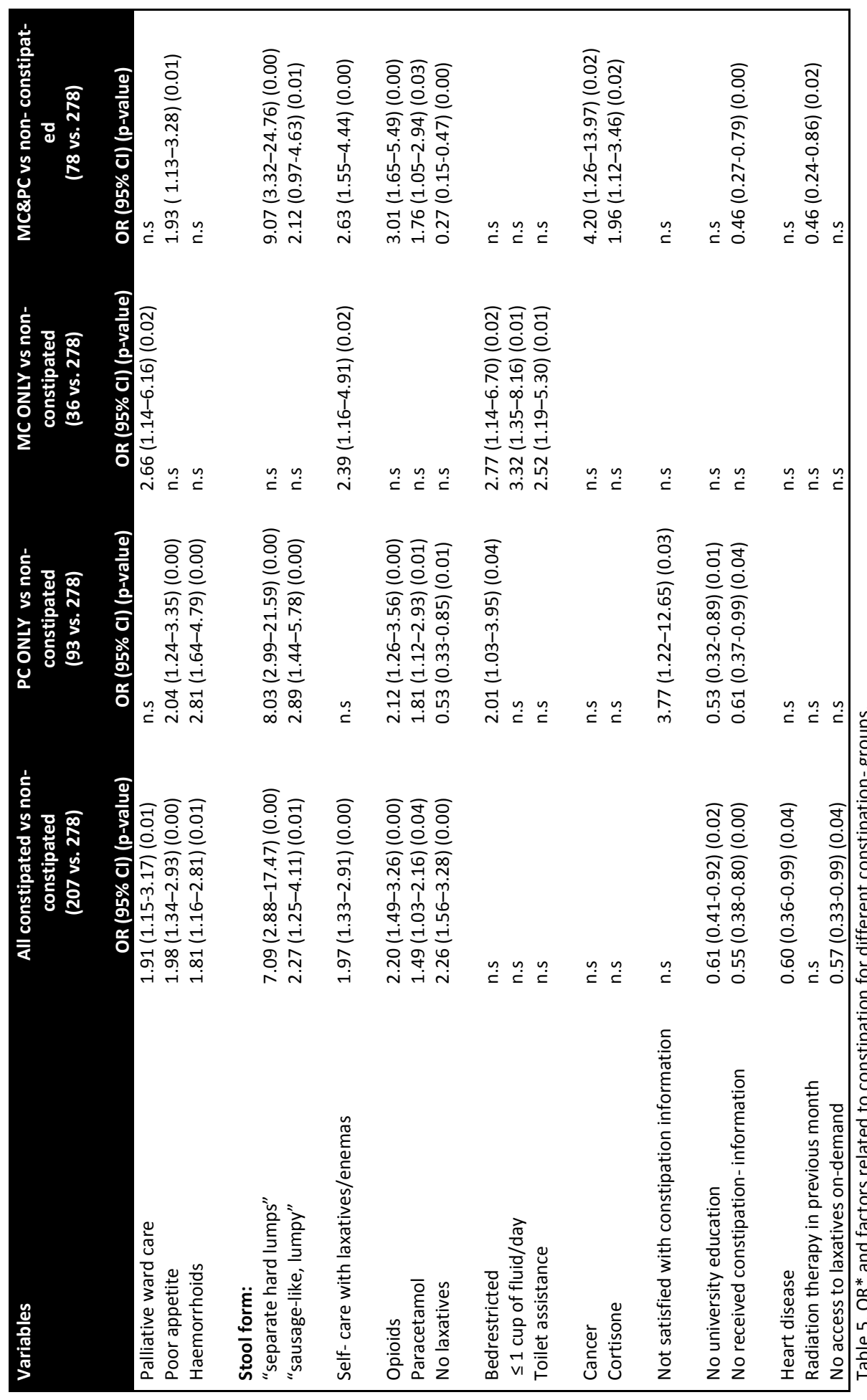




\section{DISCUSSION}

The main findings of this thesis were that constipation in specialized palliative care is highly prevalent and can be defined in different ways. Several factors related to constipation were identified as important, not only opioids.

With regard to prevalence, we found that $43 \%$ of the patients were constipated. This prevalence is much higher than in the general population, where constipation has been found to be 2-30 \% (Garrigues, Galvez et al. 2004). However, in patients with cancer and opioid-treatment for pain management, more than $84 \%$ have reported to be constipated (Abramowitz, Béziaud et al. 2013) which is much higher than our findings. The identified prevalence in the current thesis might also seem low and one reason for this could be that constipation is adequately treated in Sweden, is not seen as a big problem, or that constipation is not specifically assessed or identified. The latter was confirmed by the participating units in this thesis, as the majority of them did not have any written guidelines on specific constipation assessment. On the other hand, when considering that almost every second patient in the current studies was constipated, the prevalence is high. A reason for this might be that less than half of all constipated patients in the current studies received laxatives, although this is the recommended for treatment of constipation, (Candy, Jones et al. 2011). 
In the 1970s Henderson (1978) recommended daily recording of defecations (Henderson, Nite 1978), which could improve identification and increase prevalence. This still seems to be the case.

Prevalence is closely related to definition, and a high or low prevalence could therefore be explained by the use of different definitions. Although a definition especially for patients in palliative care has been proposed (Sykes, 2004, Larkin, Sykes et al. 2008), the definition from the ROME- criteria, is more often used. However, the use of these criteria might not be optimal for patients in palliative care. First, as previously mentioned in the Introduction, the ROME criteria were developed for another group of patients with functional constipation without irritable bowel syndrome (IBS), not comparable to patients in palliative care. Secondly, the ROME criteria contains relevant but detailed items, requiring good cognitive function in patients, and knowledge of "stool history" as far back as six months. This may be hard to assess for patients in palliative care. The definition proposed by Sykes and Larkin is more adjusted to patients in palliative care but have not been found explicitly in studies on constipation in palliative care. How to make assessments based on the definition is not clear, and this needs to be made objective and validated (Larkin, Sykes et al. 2008, Sykes, 2004). Since constipation is a common symptom, nurses should proactively assess it with validated constipation- assessment tools including patient's own experiences (Henderson, Nite 1978). This could be one way of overcoming the lack of common definitions. 
Most constipated patients in current studies, defined constipation from frequency, which is also a common definition in clinical care practice (Clark, Urban 2010). When using different definitions, patients were identified to have different types of constipation. It was a bit unexpected that patients with less than three defecations a week (MC ONLY) did not perceive themselves as constipated. Therefore, it may be assumed that these patients may not report their elimination, as they experience themselves symptomless. Nurses can easily assess constipation from days between bowel movements, but if this is not a part of routine, and objective signs are missing, or patients do not complain, constipation may be under- assessed. Fortunately, MC ONLY was the smallest constipation group.

In the light of this, it was an interesting result that, in this thesis, the largest constipation group were patients with perceived constipation (PC ONLY and MC\& PC). This needs some attention, as these patients defined constipation by experience and appearance, not by frequency, and perceived themselves as constipated, regardless of how often they had defecations. This group of patients with perceived constipation could also be a reason for underestimation (Downing, Kuziemsky et al. 2007) and low identification of constipation in studies (Rhondali, Nguyen et al. 2013). Since current assessment tools do not optimally include patients perceptions, patients have to express their problems themselves. However, it is not easy for all patients to talk about constipation, for several reasons. Firstly, constipation may be a sensitive subject, not so easily raised, or as Henderson 
pointed out "not topics of polite conversation" that patients may be embarrassed about (Henderson, 1997 p. 52). Secondly, patients may have expectations of nurses to "know", theoretically and empirically, what problems they could be expected to have as patients (Friedrichsen, Erichsén 2006). Finally, if nurses do not ask about constipation, this indicates that it is not important and patients hesitate to mention it (Friedrichsen, Erichsen 2006). Even if patients do not report constipation themselves, nurses should inform them about it. Patients with perceived constipation, in this thesis, were not satisfied with provided information. Even if we do not know who gave them the information on constipation it is important that nurses have knowledge of this basic need (Henderson 1982, Henderson, Nite 1978).

Although nurses may objectively identify constipation, preferably with validated constipation assessment tools, this symptom also has to be explored and discussed together with the patient (Börjesson, Starkhammar et al. 2012). Unfortunately, communication has been reported to be an unmet need for patients in palliative care (Ventura, Burnley et al. 2014). Without communication, symptomrelief will become very hard to achieve (World Health Organization 2002) and the patient's perception of elimination problems, will never be known. To conclude, there are several explanations for variations in the prevalence of constipation. 
Distress from constipation was found for all patients with the perception of being constipated. Patients with "only" a perception of being constipated (PC ONLY), were less often constipated and less distressed by their constipation, but as severely constipated, as patients with "objective" symptoms (MC\&PC). This is an interesting result, as it points out that although constipation may not be objectively observed or measured; patient's well- being may be affected, due to constipation (Börjesson, Starkhammar et al. 2012). Therefore a more holistic way to define constipation is needed, in which both objective and subjective assessments should be incorporated. Henderson described that nurses should be able to judge patients elimination- needs, both from "normal" ranges, appearance, odour and patients emotions (Henderson 1997). If nurses do not recognise patient's beliefs and responses, such as distress on constipation- problem (Dodd, Janson et al. 2001, Zambroski, Moser et al. 2005) patients may feel neglected, helpless and suffer (Friedrichsen, Erichsen et al. 2006). Empowering patients, reduce suffering and improve quality of life is three of nurse's important roles in palliative care (Henderson 1997, World Health Organization 2006).

In this thesis, many factors related to constipation were identified. Some of them were in the nursing domain, like dissatisfaction with information on constipation, and some were in other domains as medication. Some factors can be changed, such as improvement of information on constipation and personal care to patients, assisting them with elimination needs, when necessary (Henderson 1997, Henderson, Nite 1978). Others factors might not be changeable like the diagno- 
sis. But the diagnosis is still useful to identify patients with a high risk of developing constipation. Although medical treatment with laxatives for prevention of constipation, is not in the nursing domain, nurses may influence this through improved assessments and evaluations of constipation. Normal basic human needs may be overseen by nurses. Proactive nursing is needed even for patients at the end of life (Henderson, Nite 1978, Verschuur, Groot et al. 2014). To conclude, more factors related to constipation needs to be assessed, as they contribute to constipation more than side- effects from opioids. This would lead to a deeper understanding of constipation for patients in palliative care.

\section{Methodological issues and limitations}

For this thesis, a cross sectional design with self- reports from patients admitted to different specialized palliative care- units in Sweden, were conducted, to reach an overview of constipation. This design describes status and relationships, from one occasion, and in this way, data on constipation from the present could be retrieved. A longitudinal study could have been used, but loss of participants, due to patients deteriorating diseases in palliative care is challenging, and therefore this design was not considered (Polit, Beck 2012).

In this thesis a new questionnaire was constructed. When doing such a construction it is important to stress the reliability and validity. Questionnaires should be tested for example for test-retest reliability, inter-rater reliability, internal con- 
sistency, and face- and construct validity. Test-retest reliability is used to evaluate for stability over time but may be difficult if many traits change over time (Polit, Beck 2012), for instance for patients in palliative care with progressive diseases and sudden changes in symptoms (Wohleber, McKitrick et al. 2012). A pilot study in a palliative care setting was performed. To be sure to assess faceand content validity, several experts in the palliative care- field were used. There were no larger differences in judgment from the experts regarding the content. However, a more complete test would have been better to do, as some of the instruments may not have been used in specialized palliative care settings before. This will influence the generalisability of the results. One validated constipationinstrument could also have been used for these studies, but to include all identified risk factors for constipation a development of a new questionnaire was chosen.

Response- rate for the studies in this thesis were 50\% which is in line with the rate of participation for studies with patients in palliative care (Faithfull 2001). No other Swedish national study, on constipation in specialized palliative care, with this fairly large sample- size and broad assessment of constipation- related factors has been found in previous research, which is strength for these studies. It is possible that patients in the late palliative care phase may not have been included (Addington-Hall 2001). Since constipation has been found to increase in the late palliative care phase (Buzgova, Sikorova et al. 2014) these patients may have been missing. Patients declining to participate could also differ from partic- 
ipators, effecting prevalence of constipation. To exclude patients that did not speak Swedish may also have been a limitation, but was chosen for conveniencereasons. Recall bias might have been present and might be a weakness, but two weeks were considered to be possible to remember (Polit, Beck 2012). This could affect representativeness and the possibility to generalize the results.

\section{Clinical implications}

The results from this thesis reveal that many patients in palliative care are constipated. When nurses ask questions about frequency of defecation, not all constipated patients will have a frequency of less than three bowel movements a week. Therefore they may not be objectively assessed with constipation or risk of becoming constipated. These patients might also be unaware of that constipation is common and may cause severe problems if it is not prevented or treated. To help everyone, both the nurses providing daily care and the patients receiving it, validated constipation assessment tools should be used more in nursing practice.

Even if nurses have tools to help them assess constipation, this is a symptom that patients have to be able to express further. If nurses assessed constipation together with the patient it would improve information on constipation, as it would allow patients to express and explain their experiences at the same time as they will be listened to. Palliative care needs evidence based guidelines on management of constipation to improve symptom control and quality of care for patients. 
Regarding different factors related to constipation and nursing care, for example patients who not have appetite, nurses may enhance food intake by providing small portions, and help patients to eat. Even small amount of food affects the motility of the intestines (Guyton, Hall 2006). Bed-restricted patients may find it hard to drink from a laying position and nurses may assist these patients to an upright position, which will also increases intestine- motility by change in direction (Guyton, Hall 2006).

Basic needs may be easily forgotten with an increasing workload and expectations of others, but this should not result in patients being neglected and left on their own to cope with problems such as constipation. More factors related to constipation need to be incorporated in the assessment of constipation, as well as patient's perception of constipation, to improve control of this symptom. Nurses could then probably identify more patients with constipation but also identify nursing interventions suitable for both the prevention and management of constipation, and communicate these to the patients and other members of the palliative care team.

\section{Future research}

Constipation needs to be defined, especially for patients in palliative care. An international palliative care- expert group could work on a consensus statement on the definition of constipation for patients in palliative care, and make this def- 
inition clear and transformed to a measurement that is easy to use in studies and in clinics.

Furthermore, existing assessment instruments for constipation in palliative care need to be reliability and validity-tested for studies and clinical use. They also need to be developed with more evidence- based constipation- related factors, relevant to patients in palliative care. 


\section{CONCLUSION}

- The prevalence of constipation in specialized palliative is high.

- Patients are distressed from constipation, regardless if objective symptoms are present or not.

- Validated constipation assessment- tools needs to be implemented in practice and also incorporate the patient's perception of constipation.

- Several factors are related to constipation for patients in palliative care and needs to be incorporated into nursing assessment. Standard treatment with laxatives should not be the only "easy way" to manage constipation. 


\section{SUMMARY IN SWEDISH}

Svensk sammanfattning

Förstoppning i palliativ vård: förekomst, definition, lidande av symtom och risk-faktorer

\section{Bakgrund}

Förekomsten av förstoppning har i tidigare studier beskrivits med stora variationer, från 18 till $90 \%$ och är ett av de tio vanligaste symtomen bland patienter i palliativ vård. Det finns olika orsaker till förstoppning, som ex. stress, fiberfattig kost, sjukdomar och olika medicinska behandlingar. Specialiserad palliativ vård erbjuds till patienter med obotbara, livshotande sjukdomar (exempelvis cancer och kronisk obstruktiv lungsjukdom, KOL) i syfte att lindra symtom och stärka patientens livskvalitet. Den specialiserade palliativa vården erbjuder också tillgång till sjuksköterskor och läkare, med speciell kompetens i palliativ vård, dygnet runt alla dagar i veckan.

Patienterna kan befinna sig i tidigt skede av sjukdomen, med pågående lindrande behandlingar, likväl som i sent palliativ skede i livets slut. Förstoppning är ett subjektivt symtom som kan påverka patienterna både fysiskt, psykiskt, socialt och existentiellt. Tidigare studier har dock beskrivit att det finns stora skillnader mellan hur läkare och patienter definierar förstoppning, vilket påverkar hur förstoppning bedöms. Patienter tenderar att definiera förstoppning utifrån upplevelse av tarmtömning/konsistens på avföring och läkare mer av frekvens- och 
utseende på avföring. Trots att det inte finns en gemensam syn på hur förstoppning ska definieras i palliativ vård, brukar mindre än tre avföringar per vecka betraktas som förstoppning. Oavsett hur förstoppning definieras, så upplever patienter med förstoppning stort lidande. En vanlig orsak till förstoppning i palliativ vård är biverkningar från behandling med morfin- preparat, vilket ges till patienter för smärtlindring. Detta är väl känt och behandling sker oftast med samtidig behandling med laxermedel för att förhindra/ behandla förstoppning. Sannolikt finns det flera andra faktorer som påverkar uppkomsten av förstoppning och därför bör uppmärksammas och bedömas av sjuksköterskan. Att kunna "sköta sin mage” och ha avföring är ett basalt mänskligt behov, även för svårt sjuka och döende patienter även om det ibland kan betraktas som ett litet problem i denna svåra situation. Sjuksköterskor ska ha både kunskap och kompetens inom detta område, för att tidigt identifiera och förebygga förstoppning. Detta måste ske i samtal med patienten för att även efterfråga dennes uppfattningar och upplevelse av förstoppning.

\section{Syfte}

Det övergripande syftet med denna licentiatavhandling var att studera förstoppning bland patienter i specialiserad palliativ vård i Sverige.

Den första studiens syfte var att beskriva och utforska förekomst, definition och lidande av förstoppning genom att använda olika identifierade definitioner av förstoppning. Den andra studien syftade till att identifiera olika förstoppnings- 
relaterade faktorer och jämföra dessa mellan patienter med olika förstoppningstyper med patienter utan förstoppning.

\section{Deltagare och tillvägagångssätt}

Bägge studierna i denna avhandling är genomförda med samma patientgrupp. Svenska specialiserade palliativa enheter med vård dygnet runt, identifierades med hjälp av Palliativguiden 2010, vilket är en sammanställning av palliativa enheter i Sverige. Av 65 specialiserade palliativa enheter som identifierats, accepterade 38 enheter tilldeltagande i studien. För att kunna delta i studien skulle patienterna vara över 18 år och tala och förstå svenska. Patienter med nedsatt kognition exkluderades då de inte bedömdes kunna ge informerat samtycke till deltagande. Muntlig och skriftlig information angående studien lämnades till deltagande enheter och patienter innan studiestart. Slutligen deltog 485 patienter anslutna till dessa enheter i studierna.

Förekomst av- och faktorer relaterade till förstoppning studerades först $\mathrm{i}$ litteratur och utifrån bedömningsinstrument. Därefter konstruerades en enkät med 26 frågor, innehållande alla återfunna risk- faktorer till förstoppning. Frågor om vårdplats, diagnos och medicinsk behandling för patienten, besvarades av ansvarig sjuksköterska. Frågor om faktorer relaterade till förstoppning som ex. kön, ålder, rörlighet, aptit, nutrition besvarades av patienten, ensam eller med hjälp av någon närstående. För att undersöka förekomsten av och olika definitioner av förstoppning användes två frågor: "Hur ofta har Du haft avföring de senaste två veck- 
orna?” och " Har Du upplevt Dig förstoppad de senaste två veckorna?" Enkäten innehöll också frågor om lidande av förstoppning. En prov- studie genomfördes för att säkerställa att enkäten var förståelig, inte för tidskrävande för patienterna och att resultaten kunde besvara studiernas syfte. Därefter skickades enkäterna ut till enheterna och en utsedd ansvarig sjuksköterska på respektive deltagande enhet ansvarade för att patienter tillfrågades och enkäter lämnades ut och samlades ihop efter slutförande.

\section{Resultat och diskussion}

Resultat från studie I visade att $43 \%$ av de deltagande 485 patienterna var förstoppade. 171 (35\%) patienter "upplevde sig vara förstoppade" och $114(23 \%)$ patienter hade mindre än tre avföringar/vecka. Av dessa totalt 207 patienter med förstoppning var det $19 \%$ som upplevde sig förstoppade, men hade fler avföringar än tre/vecka, 7 \% som hade färre avföringar än tre/vecka men ingen upplevelse av att vara förstoppade och 16 \% som både upplevde sig förstoppade och hade färre avföringar än tre/vecka.

Förstoppning kan definieras på olika sätt och i detta resultat framkom tre olika förstoppnings-typer: patienter med avföring mer sällan än tre gånger/vecka (det som ofta definieras som förstoppning av t.ex. läkare) men som inte upplevde sig vara förstoppade. Detta var den minsta förstoppningsgruppen med 36 patienter (7 \%). En annan grupp var patienter som hade avföring oftare än tre gånger/vecka men som ändå upplevde sig vara förstoppade. Detta var den största gruppen med 
93 patienter (19\%). En tredje grupp med 78 patienter (16\%) hade både avföring mer sällan än tre gånger/vecka och upplevelse av att vara förstoppade. Slutsatsen som kan dras utifrån denna studie är att patienter kan ha avföring varje dag men ändå uppleva sig förstoppade. Dagar mellan avföringar kan därför inte vara det enda eller den "vanligaste" faktorn som förstoppning bedöms utifrån. Patienternas upplevelse behöver identifieras och diskuteras, mellan sjuksköterskan och patienten, för att höja kvaliteten på bedömning av förstoppning. Oavsett hur förstoppning definierades i dessa studier, så innebar förstoppning ett lidande för patienter som upplevde sig förstoppade.

Studie II visade att flera faktorer än enbart biverkningar från smärtlindrande morfin- preparat var relaterade till förstoppning. Vård på sjukhus, dålig aptit, hemorrojder, hård avföring och avsaknad av laxermedel vid samtida behandling med morfin- preparat, är exempel på faktorer som framkom i detta resultat. Då det finns många faktorer som kan relateras till förstoppning, behöver alla dessa bedömas. Riktlinjer behöver användas systematiskt i vården av patienter i palliativ vård.

Sammanfattningsvis så är förekomsten av förstoppning hög bland patienter i palliativ vård, nästan varannan patient besväras av detta. En förklaring till detta kan vara hur förstoppning definieras men oavsett definition, eller om det är märkbart utåt för sjuksköterskor, så lider patienterna av detta symtom. Bedömningar behöver göras av sjuksköterskan med vetenskapligt utarbetade bedömnings- instru- 
ment, specifikt utformade för förstoppning. Många olika orsaker, eller faktorer till förstoppning behöver bedömas, både för att förebygga men även behandla förstoppning. Detta kan ge en mer detaljerad bild över den specifika patientens orsak/orsaker till problemet och bör dessutom göras tillsammans med patienten och dennes erfarenheter och upplevelser av förstoppning. Laxermedel kan vara en bra behandlingsmetod men bör inte vara en rutin- åtgärd, utan föregående bedömning.

Att "sköta magen" är ett grundläggande behov hos alla människor, men kan vara ett känsligt och generande ämne att prata om. Patienterna ska inte behöva, och kan heller inte alltid, ta eget initiativ till att prata om avföringsproblem som förstoppning. Det ska ingå i sjuksköterskans dagliga omvårdnad av patienten. 


\section{ACKNOWLEDGEMENTS}

At last, I would like to express my gratitude to all those who have supported me in this work. A special thanks to:

Maria Friedrichsen, my head- tutor, for your support and believe in me. You have helped me reflect, and grow, on many aspects along the way.

Anna Milberg, my tutor, thank you for all your support on statistical matters and for your comments and engagement in my work.

Tiny Jaarsma, my tutor, for kind support and for patiently listening to my arguments and guiding me forward.

Maria Jacobsson, my boss, for your support and for your patients in listening to me.

To my husband Claus, who has patiently waited for me to finish this work and to my son, Mikael, for his practical support with "computer technicalities".

Last, but not least, to all participating patients in the specialized palliative care units, who kindly gave of their time to me and this research. This result is for you. 


\section{REFERENCE LIST}

ABRAMOWITZ, L., BÉZIAUD, N., LABREZE, L., GIARDINA, V., CAUSSÉ, C., CHUBERRE, B., ALLAERT, F.A. and PERROT, S., 2013. Prevalence and impact of constipation and bowel dysfunction induced by strong opioids: a crosssectional survey of 520 patients with cancer pain: DYONISOS study. Journal of Medical Economics, 16(12), pp. 1423-1433. doi:

10.3111/13696998.2013.851082. Epub 2013 Oct 25.

ADDINGTON-HALL, J.M., 2001. Survey research in palliative care using bereaved relatives. In: FIELD, D. CLARK, D. CORNER,J. DAVIS,C., ed, Researching Palliative Care. pp. 27-36. Philadelphia, Open University Press.

AOUN, S., O'CONNOR, M., DEAS, K., SKETT, K. and SMITH, J., 2012. Do models of care designed for terminally ill 'home alone' people improve their endof-life experience? A patient perspective. Health and Social Care in the Community, 20(6), pp. 599-606.

AYAZ, S. and HISAR, F., 2014. The efficacy of education programme for preventing constipation in women. International Journal of Nursing Practice, 20, pp.275-282.

BADER, S., JAROSLAWSKI, K., BLUM, H.E. and BECKER, G., 2011. Opioid-induced constipation in advanced illness: safety and efficacy of Methylnaltrexone Bromide. Clinical Medicine Insights: Oncology, 5, pp. 201-211.

BELL, T.J., PANCHAL, S.J., MIASKOWSKI, C., BOLGE, S.C., MILANOVA, T. and WILLIAMSON, R., 2009. The prevalence, severity, and impact of opioidinduced bowel dysfunction: results of a US and European patient survey (probe 1). Pain Medicine, 10(1), pp. 35-42.

BLAND, J.M. and ALTMAN, D.G., 2009. STATISTICS NOTES: Analysis of continuous data from small samples. British Medical Association, 320, pp. 1468.

BOOKBINDER, M. and MCHUGH, M.E., 2010. Symptom management in palliative care and end of life care. Nursing Clinics of North America, 45(3), pp. 271-327.

BROCK, C., SCHOU OLESEN, S., ESTRUP OLESEN, A., BRØNDUM FRØKAER, J., ANDRESEN, T. and MOHR DREWES, A., 2012. Opioidinduced bowel dysfunction: pathophysiology and management. Drugs, 72(14), pp. 1847-1865. 
BROOKS, R., 1996. EuroQol: The current state of play. Health Policy, 37, pp. 53-72.

BRUERA, E., KUEHN, N., MILLER, M.J., SELMSER, P. and MACMILLAN, K., 1991. The Edmonton Symptom Assessment System (ESAS): a simple method for the assessment of palliative care patients. Journal of Palliative Care, 7(2), pp. 6-9.

BUZGOVA, R., SIKOROVA, L. and JAROSOVA, D., 2014. Assessing patients' palliative care needs in the final stages of illness during hospitalization. The American Journal of Hospice \& Palliative Care. Doi:

$10.1177 / 1049909114556528$.

BÖRJESSON, S., STARKHAMMAR, H., UNOSSON, M. and BERTERÖ, C., 2012. Common symptoms and distress experienced among patients with colorectal cancer: a qualitative part of mixed method design. The Open Nursing Journal, 6, pp. 100-107.

CANDY, B., JONES, L., GOODMAN, M.L., DRAKE, R. and TOOKMAN, A., 2011. Laxatives or methylnaltrexone for the management of constipation in palliative care patients. The Cochrane Database of Systematic Reviews, Issue 1. Art. No.: CD003448. doi: 10.1002/14651858.CD003448.pub3.

CASARETT, D.J. and KARLAWISH, J.H., 2000. Are special ethical guidelines needed for palliative care research? Journal of Pain and Symptom Management, 20(2), pp. 130-139.

CHENG, CW., KWOK, A.OL., BIAN, ZX and TSE, D.MW., 2013. A crosssectional study of constipation and laxative use in advanced cancer patients: insights for revision of current practice. Support Care Cancer, 21(1), pp. 149-156.

CLARK, K., BYFIELDT, N., DAWE., M. and CURROW, D.C., 2012. Treating constipation in palliative care: The impact of other factors aside from opioids. American Journal of Hospice \& Palliative Medicine, 29(2), pp. 122-125.

CLARK, K. and CURROW, D.C., 2011. Assessing constipation in palliative care within a gastroenterology framework. Palliative Medicine, 0(0), pp.1-8. doi:10.1177/0269216311414756.

CLARK, K. and CURROW, D.C., 2013. Constipation in palliative care: What do we use as definitions and outcome measures? Journal of Pain and Symptom Management, 45(4), pp. 753-762. doi:10.1016/j.jpainsymman.2012.03.016.

CLARK, K., LAM, L., CURROW, D.C. and AGAR, M., 2014. A prospective study to investigate contributory factors that lead to constipation in palliative care patients. Journal of Pain and Symptom Management, 47(6), pp. 1-10. doi: 10.1016/j.jpainsymman.2014.01.005. 
CLARK, K., SMITH, J. and CURROW, D., 2012. The prevalence of bowel problems reported in a palliative care population. Journal of Pain and Symptom Management, 43, pp. 993-1000.

CLARK, K., URBAN, K. and CURROW, D.C., 2010. Current approaches to diagnosing and managing constipation in advanced cancer and palliative care. Journal of Palliative Medicine, 13(4), pp. 473-476.

CLEMENS, K.E. and KLASCHIK, E., 2008. Management of constipation in palliative care patients. Current Opinion in Supportive and Palliative Care, 2, pp. 22-27.

DAVIS, M.P., 2008. Cancer constipation: are opioids really the culprit? Support Care Cancer, 16, pp. 427-429.

DHINGRA, L., SHUK, E., GROSSMAN, B., STRADA, A., WALD, E., PORTENOY, A., KNOTKOVA, H. and PORTENOY, R., 2013. A qualitative study to explore psychological distress and illness burden associated with opioidinduced constipation in cancer patients with advanced disease. Palliative Medicine, 27(5), pp. 447-456.

DODD, M., JANSON, S., FACIONE, N., FAUCETT, J., FROELICHER, E.S., HUMPHREYS, J., LEE, K., MIASKOWSKI, C., PUNTILLO, K., RANKIN, S. and TAYLOR, D., 2001. Advancing the science of symptom management. Journal of Advanced Nursing, 33(5), pp. 668-676.

DOWNING, G., KUZIEMSKY, C., LESPERANCE, M., LAU, F. and SYME, A., 2007. Development and reliability testing of the Victoria bowel performance Scale (BPS). Journal of Pain and Symptom Management, 34(5), pp. 513-522.

ECONOMOU, D., 2010. Bowel management: Constipation, diarrhea, obstruction and ascites. In: FERRELL B, COYLE N, eds. Oxford textbook of palliative nursing, 2010,pp. 269-289. Oxford, New York: Oxford University Press.

EOFF, J.C. and LEMBO, A.J., 2008. Optimal treatment of chronic constipation in managed care: review and roundtable discussion. Journal of Managed Care Pharmacy, 14(9), pp. 1-17.

ESPER, P., 2010. Symptom clusters in individuals living with advanced cancer. Seminars in Oncology Nursing, 26(3), pp. 168-174.

FAITHFULL, S., 2001. How many subjects are needed in a research sample in palliative care? In: D. FIELD, D. CLARK, J. CORNER and C. DAVIS, eds, Researching palliative care. p. 37-41. Open University Press, Birmingham. 
FRIEDRICHSEN, M., ERICHSEN, E., 2006. The lived experience of constipation in cancer patients in palliative hospital-based home care. International Journal of Palliative Nursing, 10(7), pp. 321-325.

GARNER, S., 2013. Prescribing for the Elderly. Practice Nurse, 43(1), pp. 1925.

GARRIGUES, V., GALVEZ, C., ORTIZ, V., PONCE, M., NOS, P. and PONCE, J., 2004. Prevalence of constipation: agreement among several criteria and evaluation of the diagnostic accuracy of qualifying symptoms and selfreported definition in a population-based survey in Spain. American Journal of Epidemiology, 159(5), pp. 520-526.

GOMES, B., CALANZANI, N., CURIALE, V., MCCRONE, P. and HIGGINSON, I.J., 2013. Effectiveness and cost-effectiveness of home palliative care service for adults with advanced illness and their caregivers. Cochrane Database of Systematic Reviews, The Cochrane Library, 6.

http://www.thecochranelibrary.com.

GOMES, B., CALANZANI, N., GYSELS, M., HALL, S. and HIGGINSON, I.J., 2013. Heterogeneity and changes in preferences for dying at home: a systematic review. BMC Palliative Care, 12(7). Available:

http://www.biomedcentral.com/1472-684X/12/7.

GOODMAN, M., LOW, J. and WILKINSON, S., 2005. Constipation management in palliative care: a survey of practices in the United Kingdom. Journal of Pain and Symptom Management, 29(3), pp. 238-244.

GROENVOLD, M., PETERSEN, M.A., AARONSON, N.K., ARRARAS, J.I., BLAZEBY, J.M., BOTTOMLEY, A., FAYERS, P.M., DE GRAEFF, A., HAMMERLID, E., KAASA, S., SPRANGERS, A.G., BJORNER, J.B and THEEORTC QUALITY OF LIFE GROUP., 2006. The development of the EORTC QLQ-C15 PAL: a shortened questionnaire for cancer patients in palliative care. European Journal of Cancer, 42, pp. 55-64.

GUIGOZ, Y., 2006. The minimal nutritional assessment (MNA) review of the literature- what does it tell us? Journal of Nutrition and Health Aging, 10, pp. 446-485.

GUYTON, A. and HALL, J., 2006. Textbook of Medical Physiology 11th edition, p. 781-812. Pennsylvania: Elsevier Inc.

GYSELS, M., EVANS, C.J., LEWIS, P., SPECK, P., BENALIA, H., PRESTON, N.J., GRANDE, G.E., SHORT, V., OWEN-JONES, E., TODD, C.J. and HIGGINSON, I.J., 2013. MORECare research methods guidance development: recommendations for ethical issues in palliative and end-of-life care research. Palliative Medicine, 27(10), pp. 908-917. 
HARVER, A. and MAHLER, D., 1990. The symptom of dyspnea. In: A.MAHLER, ed. Dyspnea, p.1-53. New York: Futura, Mount Kisco.

HAWLEY, P., BARWICH, D. and KIRK, L., 2011. Implementation of the Victoria Bowel Performance Scale. Journal of Pain and Symptom Management, 42(6), pp. 946-953.

HENDERSON, V., 1997. Basic principles of nursing care. USA: International Council of Nurses.

HENDERSON, V., 1982. The nursing process-is the title right? Journal of Advanced Nursing, 7, pp. 103-109.

HENDERSON, V., 1980. Preserving the essence of nursing in a technological age. Journal of Advanced Nursing, 5, pp. 245-260.

HENDERSON, V. and NITE, G. 1978. Principles and Practice of Nursing. New York: Macmillan Publishing Co.,Inc.

HERZ, M.J., KAHAN, E., ZALEVSKI, S., AFRAMIAN, R., KUZNITZ, D. and REICHMAN, S., 1996. Constipation: a different entity for patients and doctors. Family Practice, 13(2), pp. 156-159.

HJALTE, F., BERGGREN, A., BERGENDAHL, H. and HJORTSBERG, C., 2010. The direct and indirect costs of opioid-induced constipation. Journal of Pain and Symptom Management, 40, pp. 696-703.

JAARSMA, T., BEATTIE, J.M., RYDER, M., RUTTEN, F.H., MCDONAGH, T., MOHACSI, P., MURRAY, S.A., GRODZICKI, T., BERGH, I., METRA, M., EKMAN, I., ANGERMANN, C., LEVENTHAL, M., PITSIS, A., ANKER, S.D., GAVAZZI, A., PONIKOWSKI, P., DICKSTEIN, K., DELACRETAZ, E., BLUE, L., STRASSER, F., MCMURRAY, J. and ADVANCED HEART FAILURE STUDY GROUP OF THE HFA OF THE ESC., 2009. Palliative care in heart failure: a position statement from the palliative care workshop of the Heart Failure Association of the European Society of Cardiology. European Journal of Heart Failure, 11(5), pp. 433-443.

KAMAL, A.H., NIPP, R.D., BULL, J., STINSON, C.S and ABERNETHY, A.P., 2015. Symptom burden and performance status among community- dwelling patients with serious illness. Journal of Palliative Medicine, 18(6), pp. 1-3. DOI: 10.1089/jpm.2014.0381

KIRKOVA, J., WALSH, D., RYBICKI, L., DAVIS, M.P., AKTAS, A., TAO, J. and HOMSI, J., 2010. Symptom severity and distress in advanced cancer. Palliative Medicine, 24(3), pp. 330-339. 
KIRKOVA, J., RYBICKI, L., WALSH, D. and AKTAS, A., 2012. Symptom prevalence in advanced cancer: age, gender, and performance status interactions. The American Journal of Hospice \& Palliative Care, 29(2), pp. 139-145.

KITSON, A., CONROY, T., WENGSTROM, Y., PROFETTO-MCGRATH, J and ROBERTSON-MALT, S., 2010. Defining the fundamentals of care. International Journal of Palliative Nursing Practice, 16, pp. 423-434.

KRUMM, N., LARKIN, P., CONNOLLY, M., RODE, P. and ELSNER, F., 2014. Improving dementia care in nursing homes: experiences with a palliative care symptom-assessment tool (MIDOS). International Journal of Palliative Nursing, 20(4), pp. 187.

KYLE, G., 2007. Norgine risk assessment tool for constipation. Nursing Times, 103, pp. 48-49.

LAMERS, W.M., 2000. Constipation can kill. Journal of Pharmaceutical Care in Pain \& Symptom Control, 8(3), pp. 69-73.

LAMY, O., JENZER-CLOSUIT, A. and BURCKHARDT, P., 2001. Hypercalcaemia of malignancy: an undiagnosed and undertreated disease. Journal of Internal Medicine, 250(1), pp. 73-79.

LARKIN, P.J., SYKES, N.P., CENTENO, C., ELLERSHAW, J.E., ELSNER, F., EUGENE, B., GOOTJES, J.R.G., NABAL, M., NOGUERA, A., RIPAMONTI, C., ZUCCO, F., ZUURMOND, W.W.A. and EUROPEAN CONSENSUS GROUP ON CONSTIPATION IN PALLIATIVE CARE., 2008. The management of constipation in palliative care: clinical practice recommendations. Palliative Medicine, 22(7), pp. 796-807.

LAUGSAND, E.A., JAKOBSEN, G., KAASA, S. and KLEPSTAD, P., 2011. Inadequate symptom control in advanced cancer patients across Europe. Supportive Care in Cancer: 19(12), pp. 2005-2014.

LEWIS, S.J. and HEATON, K.W., 1997. Stool form scale as a useful guide to intestinal transit time. Scandinavian Journal of Gastroenterology, 32, pp. 920924.

LONGSTRETH, G.F., GRANT THOMPSON, W., CHEY, W.D., HOUGHTON, L.A., MEARIN, F. and SPILLER, R.C., 2006. Introduction: functional bowel disorders. Gastroenterology, 130, pp. 1480-1491.

MCMILLAN, S.C. and WILLIAMS, F.A., 1989. Validity and reliability of the Constipation Assessment Scale. Cancer Nursing, 12(3), pp. 183-188. 
MAZUR, M., FURGALA, A., JABLONSKI, K., MACH, T. and THOR, P., 2012. Autonomic nervous system activity in constipation-predominant irritable bowel syndrome patients. Medical Science Monitor, 18(8), pp. 493-499.

MOENS, K., HIGGINSON, I.J., HARDING, R. and EURO IMPACT., 2014. Are there differences in the prevalence of palliative care-related problems in people living with advanced cancer and eight non-cancer conditions? A systematic review. Journal of Pain and Symptom Management, 48(4), pp. 660-677.

MOUNT, B., HANKS, G. and MCGOLDRICK, L., 2006. The principles of palliative care. In: FALLON M, HANKS G, eds. $A B C$ of palliative care $2^{\text {nd }}$ ed, Malden, Mass: Blackwell Publishing, p 1-3.

NATIONELLA RÅDET FÖR PALLIATIV VÅRD. Palliativguiden 2010. Available: http://www.nrpv.se. (accessed 18/4/2013).

NOGUERA, A., CENTENO, C., LIBRADA, S. and NABAL, M., 2009. Screening for constipation in palliative care patients. Journal of Palliative Medicine, 12(10), pp. 915-920

NÜBLING, G.S., MIE, E., BAUER, R.M., HENSLER, M., LORENZI, S., HAPFELMEIER, A., IRWIN, D.E., BORASIO, G.D. and WINKLER, A.S., 2014. Increased prevalence of bladder and intestinal dysfunction in amyotrophic lateral sclerosis. Amytrophic Lateral Sclerosis Frontotemporal Degeneration, 15, pp. 174-179.

ORNSTEIN, K., WAJNBERG, A., KAYE-KAUDERER, H., WINKEL, G., DECHERRIE, L., ZHANG, M. and SORIANO, T., 2013. Reduction in symptoms for homebound patients receiving home-based primary and palliative care. Journal of Palliative Medicine, 16(9), pp. 1048-1054.

POLIT, D.F. and BECK, C.T., 2012. Nursing research: generating and assessing evidence for nursing practice $9^{\text {th }}$ ed. Lippincott Williams \&Wilkins, Philadelphia.

PORTENOY, R.K., THALER, H.T., KORNBLITH, A.B., MCCARTHY LEPORE J, FRIEDLANDER-KLAR, H., KIYASU, E., SOBEL, K., COYLE, N., KEMENY, N., NORTON, L., and SCHER., H., 1994. The Memorial Symptom Assessment Scale: an instrument for the evaluation of symptom prevalence, characteristics and distress. European Journal of Cancer 30A(9), pp. 1326-1336.

POTTER, J., HAMI, F., BRYAN, T. and QUIGLEY, C., 2003. Symptoms in 400 patients referred to palliative care services: prevalence and patterns. Palliative Medicine, 17(4), pp. 310-314.RHONDALI, W., NGUYEN, L., LYNN PALMER, J., DUCK-HEE KANG, HUI, D. and BRUERA, E., 2013. Self-reported con- 
stipation in patients with advanced cancer: A preliminary report. Journal of Pain and Symptom Management, 45(1), pp. 23-32.

RICHMOND, J.P. and WRIGHT, M.E., 2008. Establishing reliability and validity of a constipation risk assessment scale. Journal of Orthopaedic Nursing, 12(34), pp. 139-150.

SALEEM, T.Z., HIGGINSON, I.J., CHAUDHURI, K.R., MARTIN, A., BURMAN, R. and LEIGH, P.N, 2013. Symptom prevalence, severity and palliative care needs assessment using the Palliative Outcome Scale: a cross-sectional study of patients with Parkinson's disease and related neurological conditions. Palliative Medicine, 27(8), pp. 722-731.

STJERNSWARD, J., COLLEAU, S.M. and VENTAFRIDDA, V., 1996. The World Health Organization cancer pain and palliative care program. Past, present and future. Journal of Pain and Symptom Management, 12(2), pp. 65-72.

SYKES, N.P., 2004. Constipation and diarrhea. In: DOYLE D, HANKS GWC, CHERNY N, CALMAN K eds. Oxford textbook of palliative medicine $3^{\text {rd }}$. Oxford, Oxford University Press, 2004, 483-496.

TARUMI, Y.,WILSON,, M.P., SZAFRAN, O. and SPOONER, G.R., 2013. Randomized, double-blind, placebo-controlled trial of oral docusate in the management of constipation in hospice patients. Journal of Pain and Symptom Management, 45(1), pp. 2-13.

TERRY, W., OLSON, L.G., RAVENSCROFT, P., WILSS, L. and BOULTONLEWIS, G., 2006. Hospice patients' views on research in palliative care. Internal Medicine Journal, 36(7), pp. 406-413.

THE SWEDISH NATIONAL BOARD OF HEALTH AND WELFARE., 2001. Döden angår oss alla; Värdig vård vid livets slut, SOU 2001:6. Stockholm, Graphium/Nordsteds tryckeri.

THE SWEDISH NATIONAL BOARD OF HEALTH AND WELFARE., 2013. Nationellt kunskapsstöd för god palliativ vård i livets slutskede. Vägledning, rekommendationer och indikatorer, Stöd för styrning och ledning. Västerås, Edita Västra Aros.

VAN LANCKER, A., VELGHE, A., VAN HECKE, A., VERBRUGGHE, M., VAN DEN NOORTGATE, N., GRYPDONCK, M., VERHAEGHE, S., BEKKERING, G. and BEECKMAN, D., 2014. Prevalence of symptoms in older cancer patients receiving palliative care: a systematic review and meta-analysis. Journal of Pain and Symptom Management, 47(1), pp. 90-104.

VAN MECHELEN, W., AERTGEERTS, B., DE CEULAER, K., THOONSEN, B., VERMANDERE, M., WARMENHOVEN, F., VAN RIJSWIJK, E. and DE 
LEPELEIRE, J., 2013. Defining the palliative care patient: A systematic review. Palliative Medicine, 27(3), pp197-208.

VENTURA, A.D., BURNEY, S., BROOKER, J., FLETCHER, J. and RICCIARDELLI, L., 2014. Home-based palliative care: A systematic literature review of the self-reported unmet needs of patients and carers. Palliative Medicine, 28(5), pp. 391-402.

VERSCHUUR, E.M.,L., GROOT, M., M. and VAN, D.S., 2014. Nurses' perceptions of proactive palliative care: a Dutch focus group study. International Journal of Palliative Nursing, 20(5), pp. 241-245.

WALSH, D., DONNELLY, S. and RYBICKI, L., 2000. The symptoms of advanced cancer: relationship to age, gender, and performance status in 1,000 patients. Supportive Care in Cancer, 8(3), pp. 175-179.

WEE, B., ADAMS, A., THOMPSON, K., PERCIVAL, F., BURSLEM, K. and JOBANPUTRA, M., 2010. How much does it cost a specialist palliative care unit to manage constipation in patients receiving opioid therapy? Journal of Pain and Symptom Management, 39, pp. 644-654.

WOHLEBER, A.M., MCKITRICK, D.S. and DAVIS, S.E., 2012. Designing research with hospice and palliative care populations. American Journal of Hospice and Palliative Medicine, 29(5), pp. 335.

WORLD HEALTH ORGANIZATION., 2002. National Cancer Control Programs: policies and managerial guidelines $2^{\text {nd }}$ ed. Available:

http://www.who.int/cancer/media/en/408.pdf (accessed 20/08/2014).

WORLD HEALTH ORGANIZATION., 2014. Definition of Palliative Care. Available: http://www.who.int/cancer/palliative/definition/en/ (accessed 14/06/2014).

WORLD HEALTH ORGANIZATION., 2014. Strengthening of palliative care as a component of integrated treatment throughout the life course. Journal of Pain and Palliative Care Pharmacotherapy, 28, pp. 130-134.

WORLDWIDE PALLIATIVE CARE ALLIANCE., 2014. Global atlas of palliative care at the end of life. Available: www.thewpca.org (accessed 7/11/2014). ZAMBROSKI, C.H., MOSER, D.K., BHAT, G and ZIEGLER, C., 2005. Impact of symptom prevalence ans symptom burden on quality of life in patients with heart failure. European Journal of Cardiovascular Nursing, 4, pp. 198-206. 



\section{Papers}

The articles associated with this thesis have been removed for copyright reasons. For more details about these see:

http://urn.kb.se/resolve?urn=urn:nbn:se:liu:diva-117188 